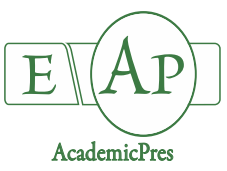

Hulujan IB et al. (2021)

Notulae Botanicae Horti Agrobotanici Cluj-Napoca

Volume 49, Issue 1, Article number 11786

DOI: $10.15835 /$ nbha49111786

Research Article

\title{
Zoophagous entomofauna and entomopathogenic agents reported on Cydalima perspectalis (Walker, 1859) in north-western of Romania
}

\author{
Ionuț B. HULUJAN, Teodora FLORIAN, Vasile C. FLORIAN*, \\ Ion OLTEAN
}

\author{
University of Agricultural Sciences and Veterinary Medicine Cluj-Napoca, Faculty of Agriculture, Plant Protection Department, \\ Calea Manastur 3-5, 400372 Cluj-Napoca,_Romania; hulujan_ionut95@yahoo.com; teodora.florian@usamvcluj.ro; \\ vasile.florian@usamvcluj.ro (*corresponding author);ion.oltean@usamvcluj.ro
}

\begin{abstract}
In Europe, the box tree moth, Cydalima perspectalis (Walker, 1859) was first reported in 2006, in southwestern Germany, then spread to almost all countries. Larvae of this species affect the aesthetic value of the box tree. In the last period, numerous studies were carried out regarding the identification of useful entomofauna that reduce the numerical density of the population of Cydalima perspectalis. In this study conducted in north-western Romania (Cluj County, in 2019), entomopathogens and useful entomofauna were monitored in four areas, represented by four cities. The entomopathogenic agents contaminated the larvae of the box tree moth in a proportion of 5.6\% at Gherla, 6.8\% at Dej, 8.7\% at Cluj-Napoca and $15.3 \%$ at Ciucea. Most larvae have been infected with Bacillus. At Cluj-Napoca and Ciucea, the presence of the larval endoparasite Exorista larvarum L. (Diptera: Tachinidae) was reported. Parasitoid species determined a parasitization rate of $5.1 \%$ at Dej, $8.6 \%$ at Gherla and $13.4 \%$ at Cluj-Napoca. Predators affected pupae in a proportion of $3.8 \%$ at Gherla, $4.2 \%$ at Dej and $16 \%$ at Cluj-Napoca. Among the pupae predators, for the firsttime common earwig was reported, Forficula auricularia L. Entomopathogenic agents affected $5.3 \%$ of the pupae collected from Cluj-Napoca, $7.7 \%$ in Gherla and $12.5 \%$ in Dej. During the monitoring period of the zoophagous entomofauna and the entomopathogenic microorganisms, affected the pupae in a percentage of $20.1 \%$ in Gherla, $21.8 \%$ in Dej, 34.7\% in Cluj-Napoca, contributing to the diminution of the population of the harmful species.
\end{abstract}

Keywords: box tree moth; Forficula auricularia; parasites; predators

\section{Introduction}

The box tree moth, Cydalima perspectalis (Walker, 1859), has its natural range in eastern Asia (India, China, Korea, Taiwan, Japan and eastern Russia). In Europe, it was first reported in 2006, in southwestern Germany (however, the species was probably introduced in 2005, but the attack was not initially noted). It was introduced with infested bush cuttings (Billen, 2007; Krüger, 2008). Then the species spread rapidly to other

Received: 15 Jan 2020. Received in revised form: 22 Jan 2021. Accepted: 01 Feb 2021. Published online: 10 Feb 2021.

From Volume 49, Issue 1, 2021, Notulae Botanicae Horti Agrobotanici Cluj-Napoca journal will use article numbers in place of the traditional method of continuous pagination through the volume. The journal will continue to appear quarterly, as before, with four annual numbers. 
European countries (Hellers and Christian, 2016; Bury et al., 2017; Nagy et al., 2017; Raineri et al., 2017; Agius, 2018; Matsiakh et al., 2018; Perez and Guillem, 2019).

The spreading area of the species extends due to the anthropic factor, which was widespread with the biological planting material infested with eggs and larvae of this species (Brua, 2013; Akatov, 2015).

In Romania, the species was reported in 2010 in the Bucharest area (Iamandei, 2010). Then, the areal expanded continuously, so that in 2014 it produced significant attacks in Timiş, Constanţa and Botoşani Counties, in 2015 in the Cluj area, and in 2016 in the Maramureş, Satu Mare and Sălaj areas (Székely et al., 2011; Fora and Poșta, 2015; Bunescu and Florian, 2016).

The larvae of this species feed on the leaves of different bush species: Buxus microphylla, B. microphylla var. insularis, B. sempervirens, B. colchica, B. sinica, B. balearica (Korycinska and Eyre, 2009; Leuthardt et al., 2010; Van der Straten et al., 2010; Hizal, 2012). Studies in Europe have shown that the most scathing attack was found on Buxus sempervirens var. rotundifolia, a variety preferred by females for oviposition (Leuthardt and Baur, 2013). The larvae prefer the older leaves for feeding. Under the attacked plants, large amounts of excrement are observed (Brua, 2013). Sometimes the population density is very high, causing total defoliation of the attacked plants (Leuthardt and Baur, 2013; Kenis et al., 2013), causing the plants to dry out. When the foliage is destroyed, the larvae also feed on the bark of the branches (Oltean et al., 2017), causing the plant to dry.

The species is polyvoltine, the number of generations being in correlation with the thermal characteristics of the area. In the area of origin, it develops 4-5 generations (Maruyama and Shinkaji, 1987), and on the European continent, it develops 2-3 generations, with the possibility of growing in the warmer areas even the fourth generation (Korycinska and Eyre, 2009; Van der Straten et al., 2010; Leuthardt et al. 2010). The larva is the hibernated stage, usually in the age of 2 or 3 , located between two leaves, protected by silk threads (Nacambo et al., 2014). The hibernating larva tolerates well temperatures below minus $16^{\circ} \mathrm{C}$ (Raineri et al., 2017). The adult flight generally starts at the end of May or early June. They are capable of travelling at distances between 5 to $10 \mathrm{~km}$ (Van der Straten et al., 2010). Adults exhibit positive phototropism, being attracted to light sources (Göttig and Herz, 2014). Larval development ranges from 28 to 85 days, depending on the temperature (López and Eizaguirre, 2019). The pupal stage lasts around 10-51 days. A generation, in optimal conditions, can develop over 30-40 days (López and Eizaguirre, 2019).

In the dynamics of the numerical density of a pest, a unique role is played by the useful entomofauna (predators and parasites). A series of researches have been carried out regarding the identification of useful entomofauna that develops on the different stages of development of the species Cydalima perspectalis. Entomopathogenic nematodes have been reported: Steinernema carpocapsae and Heterorhabditis bacteriophora (Herz, 2013). Nemastar biopreparate (based on Steinernema carpocapsae, an endoparasitic nematode) has determinate mortality of up to $75 \%$ in second-age larvae and up to $100 \%$ in old (forth-age) larvae (Göttig and Herz, 2018). Parasitic Hymenoptera has been identified, especially in the box tree moth origin area, some of them being present on the European continent also. The most important are: Apanteles glomeratus L. Bracon brevicornis Wesmael, Bracon hebetor Say., Chelonus tabonus Sonan, Dolichogenidea stantoni Ashmead, Protapanteles mygdonia Nixon, species of Braconidae family (Brua, 2013; Göttig and Herz, 2014; Wan et al., 2014; Belokobylskij and Gninenko, 2016); Apechthis compunctor L., Casinaria sp., Ichneumonidae family (Wan et al., 2014); Trichogramma spp., Trichogramma brassicae Bezdenko and Trichogramma dendrolimi Matsumura, Trichogrammatidae family (Herz, 2013; Wan et al., 2014); Brachymeria lasus Walker, Chalcididae family (Brua, 2013; Wan et al., 2014); Tyndarichus spp., Encyrtidae family (Brua, 2013; Wan et al., 2014). Göttig and Herz (2016), verified, under laboratory conditions, the effectiveness of different Trichogramma species in parasitizing Cydalima perspectalis eggs. The species used in the experiment were: T. brassicae Bezdenko, T. bourarachae Pintureau \& Babault, T. cacoeciae Marchal, $T$. cordubensis Vargas \& Cabello, T. dendrolimi Matsumura, T. evanescens Westwood, T. nerudai Pintureau \& Gerding, and T. pintoi Voegele. Trichogramma dendrolimi Matsumura gave the best results, and the parasitic rate was about $40 \%$. Also, Tabone et al. (2015) tested 54 strains from 17 Trichogramma species and found that 
five strains are highly virulent. From the Diptera order, the Tachinidaefamily were reported Exorista larvarum L., Pseudoperichaeta nigrolineata Walker and Compsilura concinnata Meigen (Shi and Hu 2007; Kenis et al., 2013; Wan et al., 2014; Farahani et al., 2018; Martini et al., 2019; Bird et al., 2020). Di Vitantonio (2016), in laboratory conditions, observed a high parasitic rate of larvae by the Exorista larvarum L.

Natural predators are very few because larvae of this species have a very high content of alkaloids, derived from the composition of the box tree leaves (Leuthardt et al., 2013; Brua, 2013; Martin et al., 2018). Larvae have been found to retain bi-basic alkaloids in the body, while monobasic alkaloids are metabolized or excreted. Some species of birds consume only adults that do not contain alkaloids and avoid larvae consumption (Leuthardt et al., 2013). However, the most famous predator is Vespa velutina Lepeletier (Hymenoptera; Vespidae), a species present in Europe (Leuthardt and Baur, 2013; Brua, 2013; Wan et al., 2014; Feás and Charles, 2019). However, Mostini (2018) in Piedmont (NW Italy) in 2016 reported that some birds consumed the larvae such as Turdus merula L. and Parus major L.; and in the north of the Netherlands by Haematopus ostralegus L., Parus major L., Cyanistes caeruleus L., Pica pica L., Sturnus vulgaris L. and Passer domesticus L. Martin et al. (2018), also reported that Parus spp. has a low predatory rate for this pest. In Slovakia, Bakay and Kollár (2018) said that adults of Cydalima perspectalis are consumed by Passer domesticus L., Parus major L., Turdus merula L. and Ficedula albicollis Tem. They also found that the melanic form of box tree moth did not attract these birds. Predators that feed on eggs of the species Cydalima perspectalis are considered the most important, because the eggs do not contain toxins, such as bi-basic alkaloids that are accumulated in the body of the larvae. Therefore, it is expected that the release of Chrysopa carnea, Harmonia axyridis and Orius majusculus species, raised in biostations, could represent a natural alternative of pest control (Herz, 2013).

Perspective entomopathogenic agents in Cydalima perspectalis species control are: Anagrapha falcifera nucleopolyhedrovirus (AnfaNPV) baculovirus, Bacillus thuringiensis var. kurstaki, Bacillus thuringiensis var. aizawai, Beauveria bassiana (Brua, 2013; Kenis et al., 2013; Rose et al., 2013; Tabone et al., 2015; Zamani et al., 2017). Harizanova et al. (2018) in a study carried out in five locations in Bulgaria, in the gut of larvae of Cydalima perspectalis reported five bacteria (Acinetobacter schindler, Enterococcus casseliflavus, Klebsiella mobilis, Paenibacillus anaericanus and Paenibacillus popilliae) and five species of fungi (Metarhizium sp., Beauveria sp., Verticillium sp., Alternaria sp. and Mucorsp.). A series of studies are being undertaken regarding the possibility of using bioproducts (Göttig and Herz, 2014; Wan et al., 2014).

In landscaping and for green hedges in public space and residential zones of Cluj-Napoca, Romania (representing over $120 \mathrm{~km}$ after R.A.D.P Cluj-Napoca statistics), one of the main species used is Buxussp. The aesthetic value of these species has been severely affected since 2015 by the invasive species Cydalima perspectalis. In strong attacks, in addition to deteriorating the aesthetic value of the plants, partial or total drying of the plants occurred (Figure 1). This situation was manifested with maximum intensity in the USAMV Cluj-Napoca Park and Hasdeu Campus. Since 2016, the Entomology discipline of USAMV ClujNapoca was proceeded to an extensive bioecology studies of the box tree moth (Oltean et al., 2017). An unusually high frequency and intensity of the attack was also reported on the box tree plants in the parks located in other cities of Cluj County, in Ciucea, Dej and Gherla. Considering the importance of the zoophagous entomofauna and the entomopathogenic agents in the population density dynamics of this species, the study of this aspect in the landscape arrangements from Cluj County has started. 


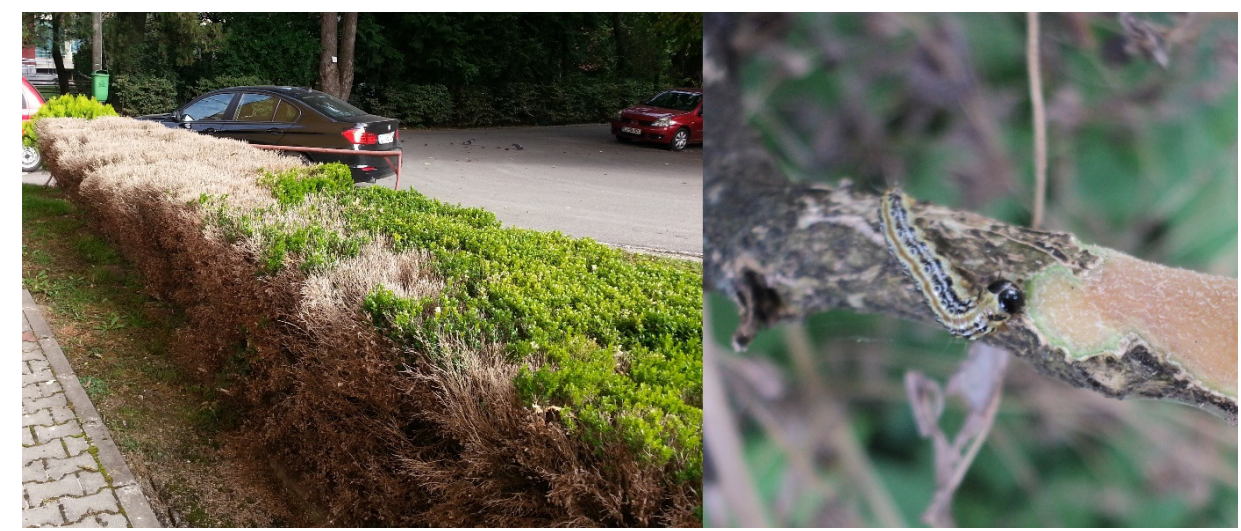

Figure 1. Cydalima perspectalis Walker attack, USAMV Cluj-Napoca campus (photo I. Hulujan)

\section{Materials and Methods}

\section{Geographical location of the study}

In 2019, the first researches were started regarding the monitoring of useful entomofauna and entomopathogenic agents that affect the population of Cydalima perspectalis from the parks of the main cities of Cluj county, N-W of Romania.

The observations were made in four locations: Cluj-Napoca, in the Hasdeu university campus, (coordinates $46^{\circ} 46^{\prime} 0^{\prime \prime} \mathrm{N}, 23^{\circ} 35^{\prime} 0^{\prime \prime} \mathrm{E}$ ); Ciucea, in the park of the Octavian Goga memorial house (coordinates $46^{\circ} 57^{\prime} 56^{\prime \prime} \mathrm{N}, 22^{\circ} 49^{\prime} 23^{\prime \prime} \mathrm{E}$ ); Gherla, in the park of the Armenian Catholic Cathedral (coordinates $47^{\circ} 01^{\prime} 0^{\prime \prime} \mathrm{N}$, $23^{\circ} 53^{\prime} 0^{\prime \prime} \mathrm{E}$ ); and Dej, in the central park (coordinates $47^{\circ} 08^{\prime} 32^{\prime \prime} \mathrm{N}, 23^{\circ} 52^{\prime} 29^{\prime \prime} \mathrm{E}$ ).

\section{Biological material}

In Cluj-Napoca and Ciucea, the biological material was collected on 2019.09.26, and 2019.10.07 in Dej and Gherla. On the hedge alignments with box tree, three sections were randomly established (each section represents a repetition) with a length of $5 \mathrm{~m}$ (a total of $15 \mathrm{~m}$ for each location), from which the larvae and pupae were taken. In order to be able to make the statistical interpretation in each location, they were collected separately on each repetition (section) noting the location and the number of the repetition. The day after the biological material was collected, it was analyzed in the laboratory. In the first stage, the larvae and pupae of each sample were separated into two categories: healthy and attacked by the zoophagous entomofauna or entomopathogenic agents. Infested or contaminated larvae and pupae were analyzed with a binocular magnifying glass. In larvae, the frequency of their contamination with entomopathogens was determined. In pupae, the percentage of parasitic specimens, partially consumed by predators, and also those infested with entomopathogens was determined.

\section{Analysis of endoparasites}

The parasitized pupae had an orifice left by endoparasites. Assuming that the endoparasites did not entirely abandon the pupae attacked by endoparasites, the healthy pupae at the first evaluation were kept in the laboratory for 14 days at an average temperature of $25^{\circ} \mathrm{C}$. The literature shows that the pupal stage at this temperature lasts on average, 10.2 days (López and Eizaguirre, 2019). Pupae from which no adults appeared were re-analyzed, and corrections were made to the results noted in the first analysis. The total larvae collected were: 342 in Cluj-Napoca, 418 in Ciucea, 266 in Dej and 213 in Gherla. The number of pupae collected was: 558 in Cluj-Napoca, 348 in Dej and 279 in Gherla. The results obtained were statistically processed using the analyze of variance, completed by the Duncan test when the value $\mathrm{F}$ was statistically assured. 


\section{Results and Discussion}

Frequency of larvae contaminated with entomopathogens

Figure 2 shows the percentage of larvae contaminated with entomopathogenic agents in the monitored locations. The value of this parameter is different from one location to other. In Cluj-Napoca, out of the 342 examined larvae, the contaminated larvae were in a proportion of $8.7 \%$, with oscillations between $4.2 \%$ and 11.3\%. In Ciucea, the highest frequency of contaminated larvae was reported. Of the 418 larvae collected, $15.3 \%$ were contaminated. The frequency of contaminated larvae was between $10.8 \%$ and $18.2 \%$. As can be seen from figure 2 , the difference between this locality and the other three localities is statistically assured (SD $=5.33-5.63)$. In Dej, 266 larvae were analyzed, and the percentage of larvae contaminated was between 4.6\% and $9.6 \%$, with an average of $6.8 \%$. Gherla has the lowest percentage of infected larvae. Of the 213 larvae taken, $5.6 \%$ were infected. The differences between the percentage of larval infestation in Cluj-Napoca, Dej and Gherla are not statistically assured (SD = 5.33-5.63). In each location, most larvae were affected by bacteria of the genus Bacillus (Figure 3). The literature also states that the incidence of bacterial larval contamination is higher than that of fungi. Thus, Harizanova et al. (2018) in the observations made over three years in five locations in Bulgaria, it had average contamination of $10.2 \%$ with Bacillus anaericanus, $52.4 \%$ with Bacillus popilliae, and the contamination with fungi was $28.6 \%$ with Beauveria sp., by $29.6 \%$ with Metarhizium sp., and by $13.6 \%$ with Verticillium sp.

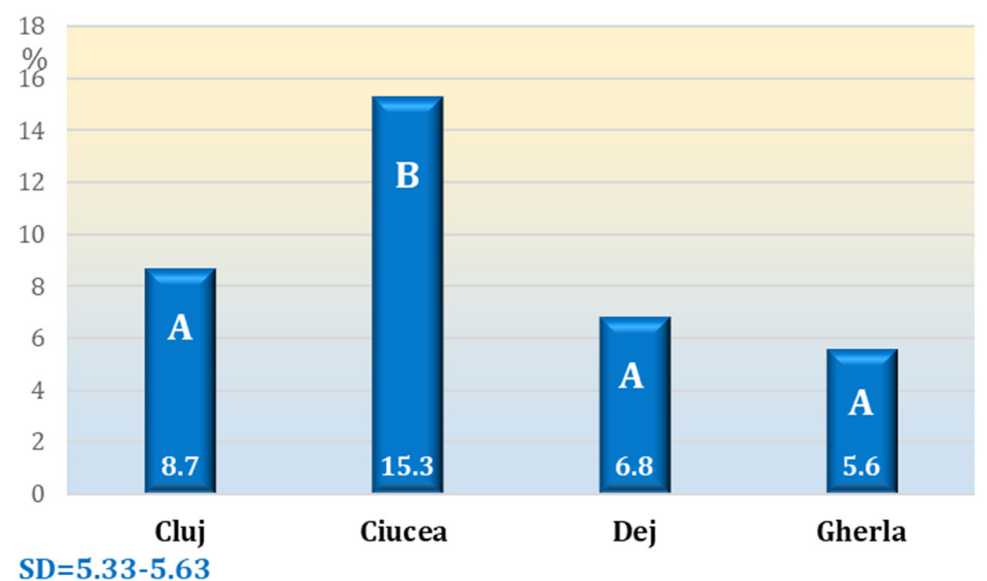

Figure 2. Percentage of $C y d a l i m a$ perspectalis Walker larvae contaminated with entomopathogens

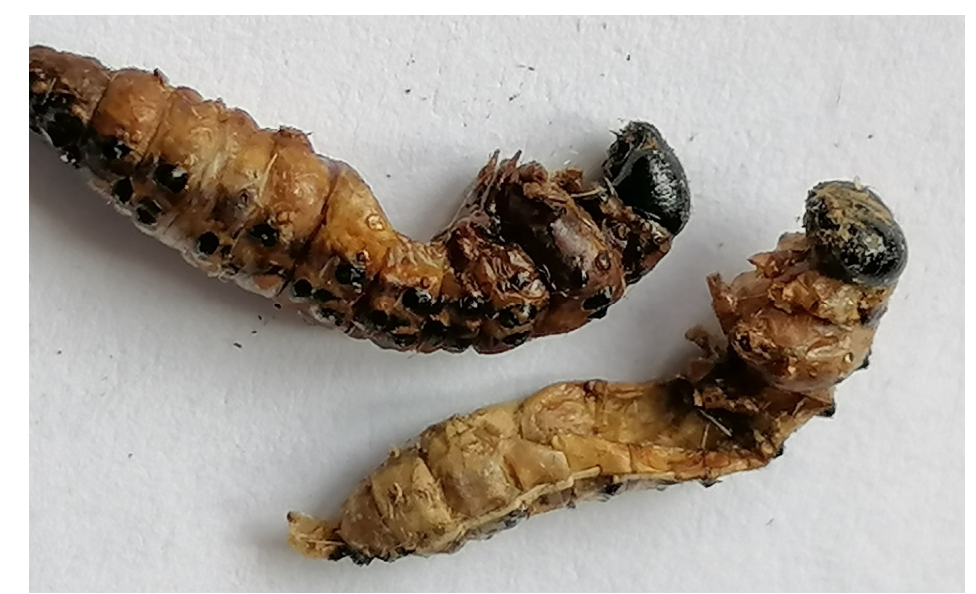

Figure 3. Cydalima perspectalis Walker larvae contaminated with entomopathogens (photo I. Hulujan) 
In Cluj-Napoca and Ciucea, we reported eggs and attack symptoms produced by the endoparasitic Exorista larvarum L. (Figure 4). In Cluj-Napoca, the proportion of infected larvae was 3.7\%, and in Ciucea $5.2 \%$. This parasite belongs to the order Diptera, family Tachinidae. It is a polyphagous species that parasites the larvae of many species of Lepidoptera. The adult lays an egg on the exoskeleton of the host larva (Figure 4a). After hatching the larvae enter the body of the parasite-host, and at the place of penetration, a dark spot appears due to the melanization of the skin (Valigurová et al., 2014). In the parasitized larva, the phenomenon of cellular defense manifested by the formation of a haemocyte capsule of multi-cellular sheaths (Figure 4b). Di Vitantonio (2016) and Martini et al. (2019) under laboratory conditions found that, although the larvae of the species Exorista larvarum L. parasitized the larvae of Cydalima perspectalis causing their death, they did not complete their biological cycle. They died because the host encapsulated them. However, this endoparasite can cause a decrease in the population density of the box tree moth, because the endoparasite is maintained on other species of Lepidoptera in the ecosystem. In the area of origin of the species, Cydalima perspectalis the mortality of larvae caused by Exorista sp., it was between 32.6\% and 47.5\% (Shi and $\mathrm{Hu}, 2007$ ).

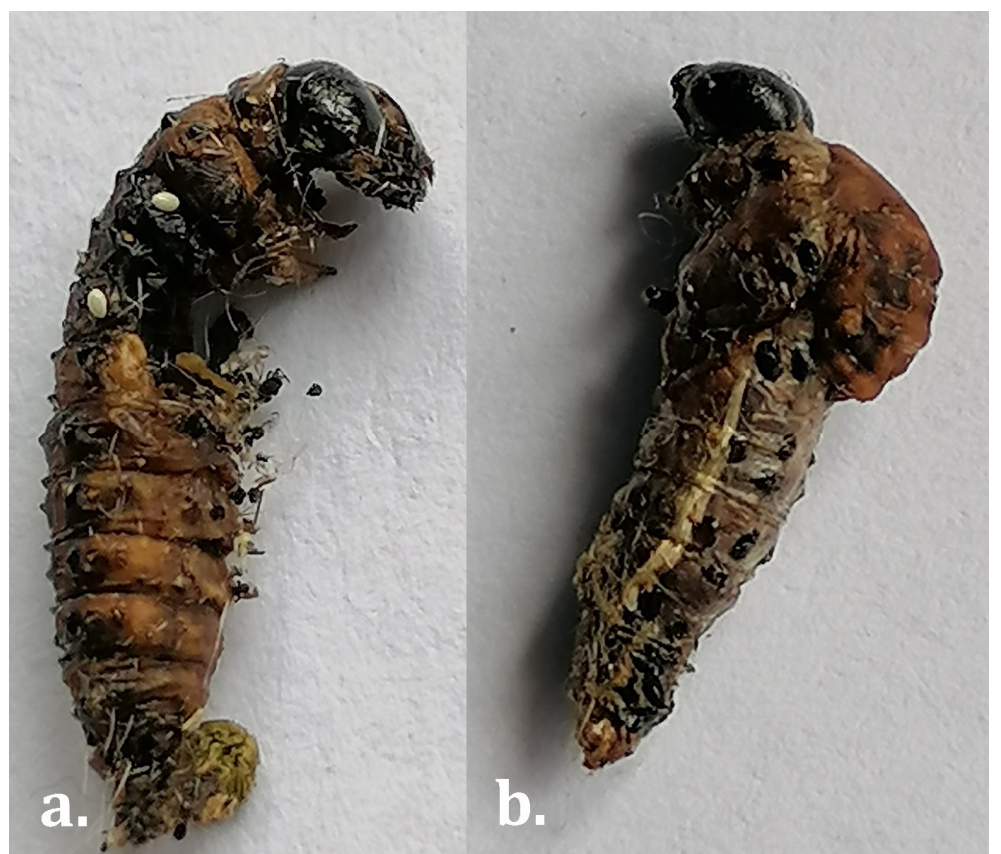

Figure 4. a) Cydalima perspectalis Walker larvae with eggs of Exorista larvarum L. b) microencapsulated Exorista larvarum L. larvae (photo I. Hulujan)

\section{Frequency of pupae attacked by parasites}

Regarding the parasitism rate of Cydalima perspectalis pupae between the three monitored locations, there are statistically assured differences $(\mathrm{SD}=1.89-1.93$ ) (Figure 5). In the Asian area where the native area of this pest is, specific parasites have been reported, such as the braconid Chelonus tabonus, which are not found in Europe. The literature shows that the pupae of many species from the families Tortricidae, Pyralidae, Pieridae, Lycaenidae are parasitized by polyphagous parasites, which can even affect the pupae of Cydalima perspectalis (Wan et al., 2014).

At Cluj-Napoca, 558 pupae were analyzed. It is the location where the highest proportion of parasitism of pupae was reported. The percentage of parasitism ranged from $9.2 \%$ to $18.8 \%$, with an average of $13.4 \%$, these having obvious holes through which different parasitoid species left the parasitized pupae (Figure 6). The high percentage of parasitization of the pupae is undoubtedly determined by the fact that in this location no chemical treatments were applied in 2019, which allowed the development of a more numerous parasitoid entomofauna. 


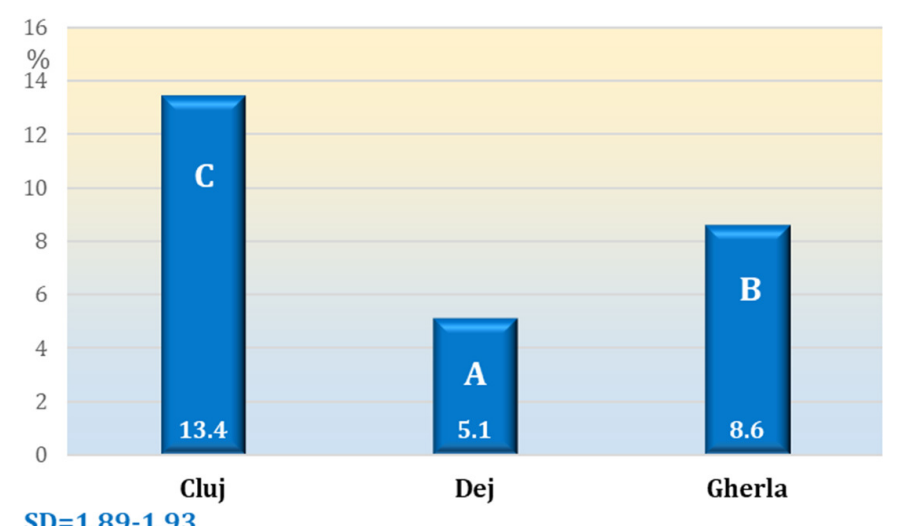

Figure 5. Percentage of parasitized pupae

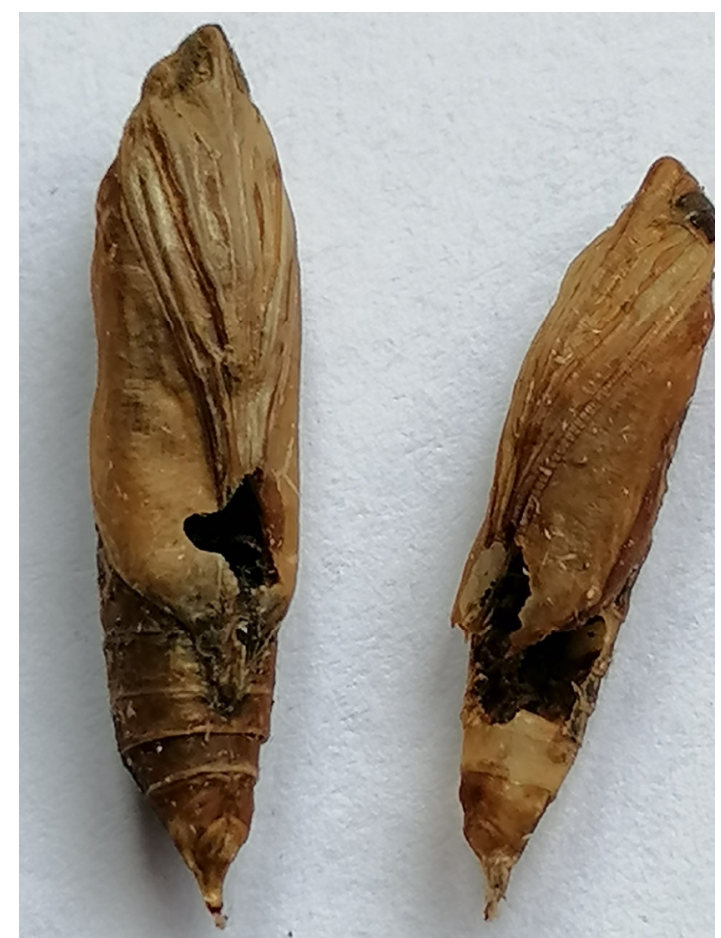

Figure 6. Parasitized pupae of Cydalima perspectalis Walker parasite (photo I. Hulujan)

In the biological material collected from Cluj-Napoca and brought to the laboratory, a parasitic wasp from the Eulophydae family also appeared, which laid its eggs on viable pupae from the storage pots (Figure 7).

In Dej, 348 pupae were analyzed, and the percentage of parasitized pupae was 5.1\% (with oscillations between $3.5 \%$ and $7.8 \%$ ). In this location was the lowest percentage of parasites of the pupae. In Gherla, the average percentage of parasitism was $8.6 \%$ (with oscillations between $7 \%$ and $11.4 \%$ ).

Two chemical treatments were applied in Dej and Gherla this year. The first treatment was applied in June using a synthetic pyrethroid (Karate Zeon - 0.02\%), and the second treatment in August with Mospilan 20 SC - $0.02 \%$. These insecticides have been frequently used to control this pest (Rose et al., 2013; Raineri et al., 2017). These insecticides certainly affected the zoophagous entomofauna, which determined a lower percentage of parasitism compared to the one reported in Cluj-Napoca. 


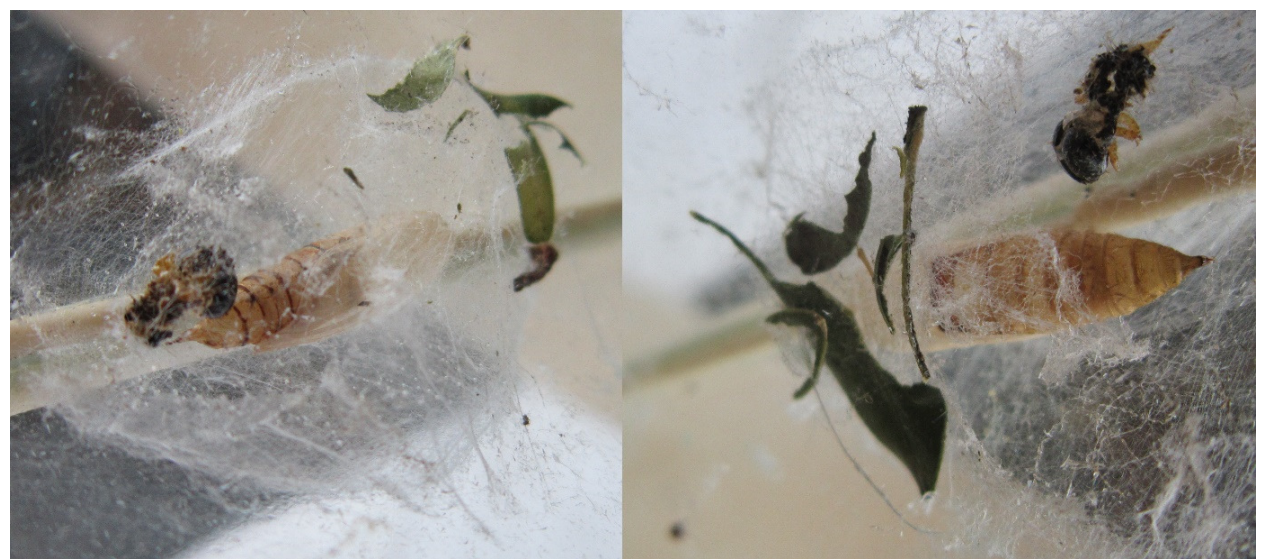

Figure 7. Parasitic wasp from the Eulophydae family depositing eggs on Cydalima perspectalis pupae (photo I. Hulujan)

\section{Frequency of pupae attacked by predators}

As shown in the literature, predators affect the larval stage to a small extent due to the alkaloids that come from the consumed Buxus leaves. In larvae, sometimes the concentration in alkaloids can be 20 times higher than in box tree leaves (Brua, 2013; Leuthardt et al., 2013). In pupae, the concentration of alkaloids is much decreased, and the frequency of pupae attacked by predators is higher compared to larvae.

Also, in the case of pupae attacked by predators, there are differences between the three localities. There are statistically assured differences between the attack reported in Cluj-Napoca and the one in the other localities. However, there are no significant differences between Dej and Gherla ( $\mathrm{SD}=2.82-2.87)$ (Figure 8).

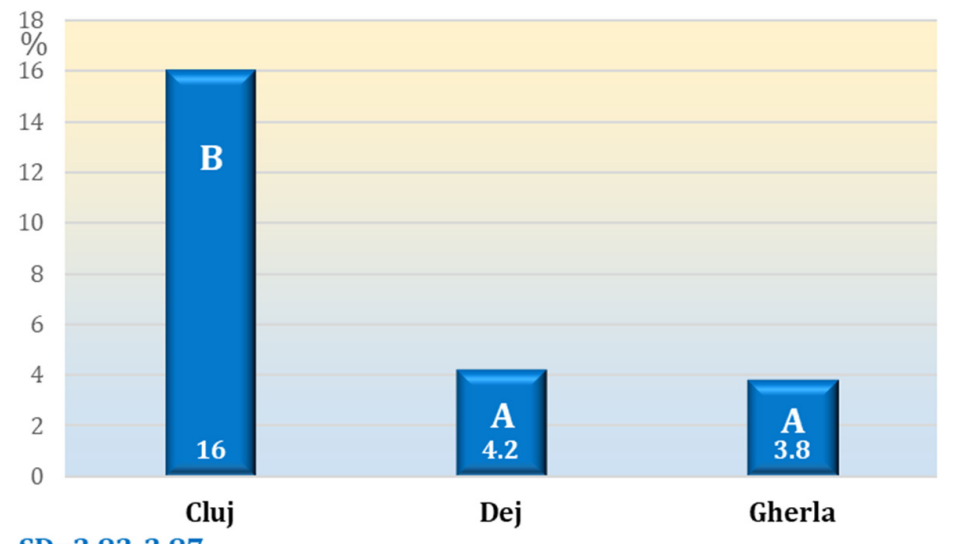

$\mathrm{SD}=2.82-2.87$

Figure 8. Percentage of pupae attacked by predators

As in the case of parasitized pupae in Cluj-Napoca, where no chemical treatments were applied to control them, compared to the other localities, the highest proportion of pupae attacked by predators was reported, the percentage of pupae attacked ranged between $12.5 \%$ and $19 \%$, with an average of $16 \%$, these having obvious symptoms being partially consumed by predators (Figure 9).

During the collection of larvae and pupae of Cydalima perspectalis, we reported on the box tree bushes 1-5 adults of Forficula auricularia L. that fed only on the pupae of this species (Figure 10). This species is a predator of the order Dermaptera, family Forficulidae. In the literature, it is mentioned as a predator of many species of phytophagous insects, but there is no reference to Cydalima perspectalis. 


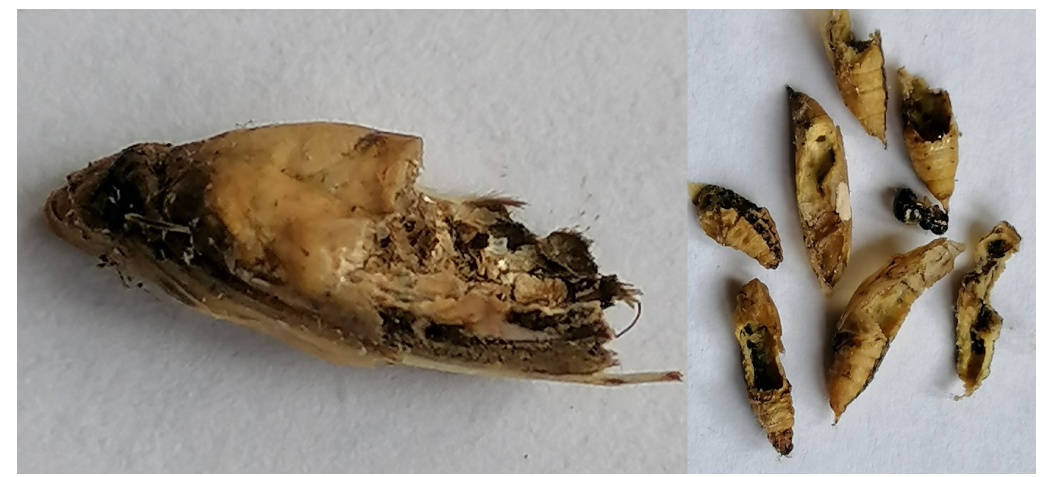

Figure 9. Cydalima perspectalis Walker pupae attacked by predators (photo I. Hulujan)

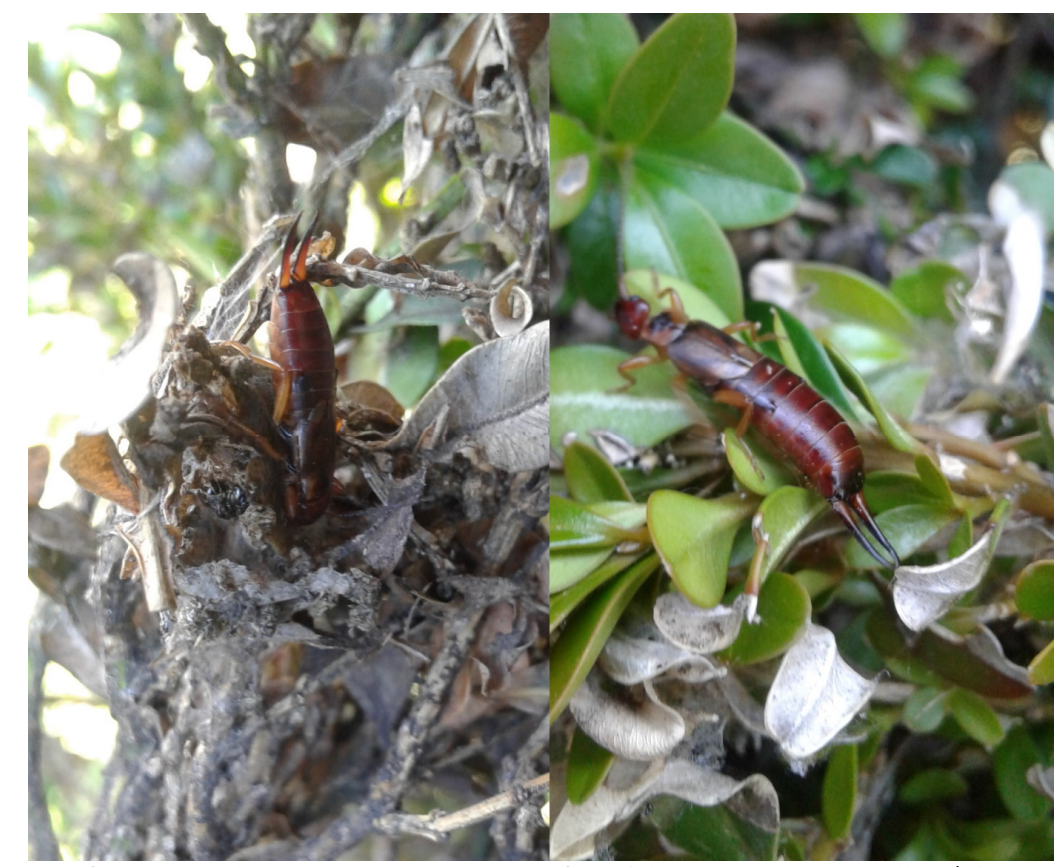

Figure 10. Forficula auricularia L. consuming pupae of Cydalima perspectalis Walker (photo I. Hulujan)

The reporting of the species Forficula auricularia L. as a predator of Cydalima perspectalis pupae is a novelty for the investigated area.

Regarding the contribution of predators in diminishing the biological reserve of the species Cydalima perspectalis in the other two locations, it was much lower. In Dej, the percentage of attacked pupae was $4.2 \%$ (between $2.5 \%$ and 6.2\%). At Gherla, the lowest frequency of attacked pupae was reported, being only 3.8\%. Here the percentage of pupae attacked in the analyzed samples ranged between $1.5 \%$ and $6.5 \%$. The difference between these two localities is not statistically assured $(\mathrm{SD}=2.82-2.87)$.

\section{Frequency of pupae contaminated with entomopathogens}

The frequency of pupae contaminated with entomopathogenic microorganisms from the three monitored locations is shown in Figure 11. The differences reported between locations are statistically assured $(\mathrm{SD}=1.94-1.98)$. In Cluj-Napoca, of the total number of pupae collected and analyzed in the laboratory, $5.3 \%$ were infected by entomopathogenic agents, here being the lowest frequency. On the analyzed samples, the percentage of infestation was between $2.8 \%$ and $7.3 \%$. 
Hulujan IB et al. (2021). Not Bot Horti Agrobo 49(1):11786

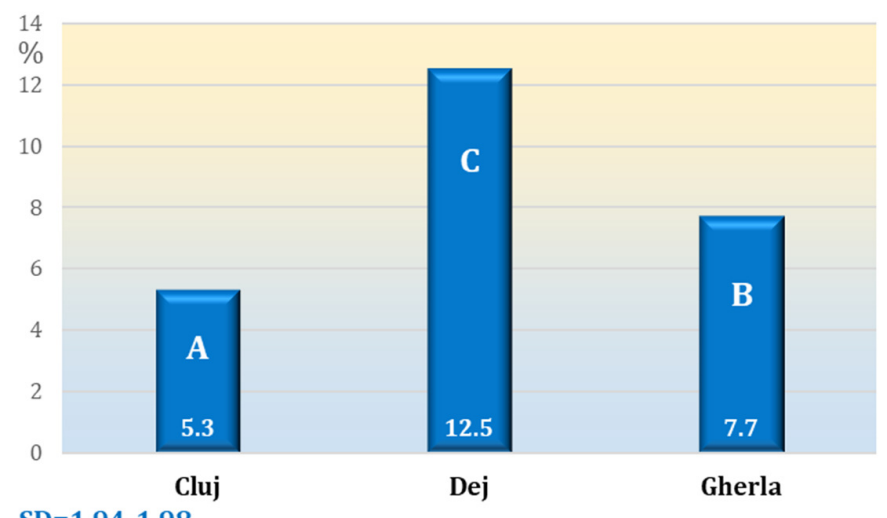

Figure 11. Percentage of pupae contaminated with entomopathogens

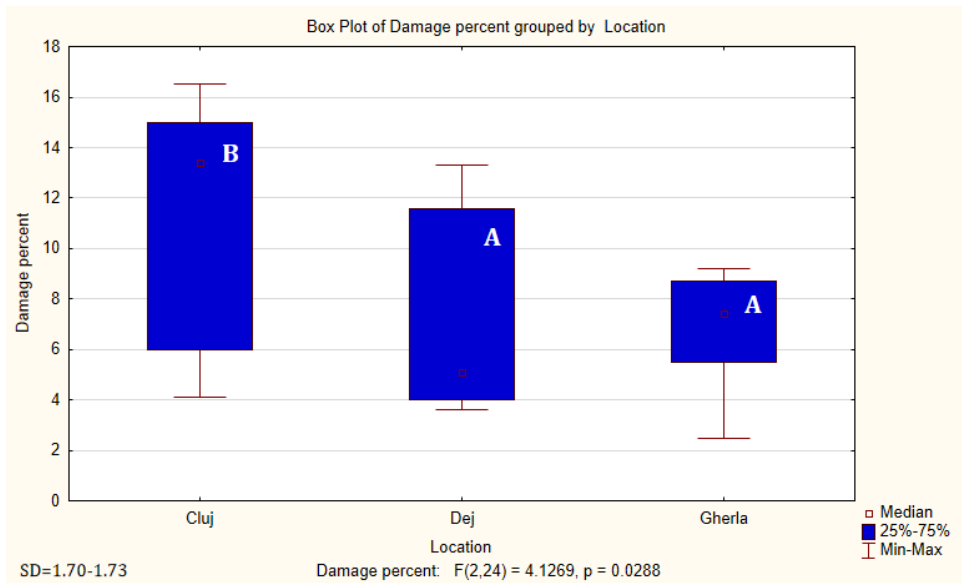

Figure 12. Cydalima perspectalis Walker pupae damaged (parasitism, predators, contamination) by location

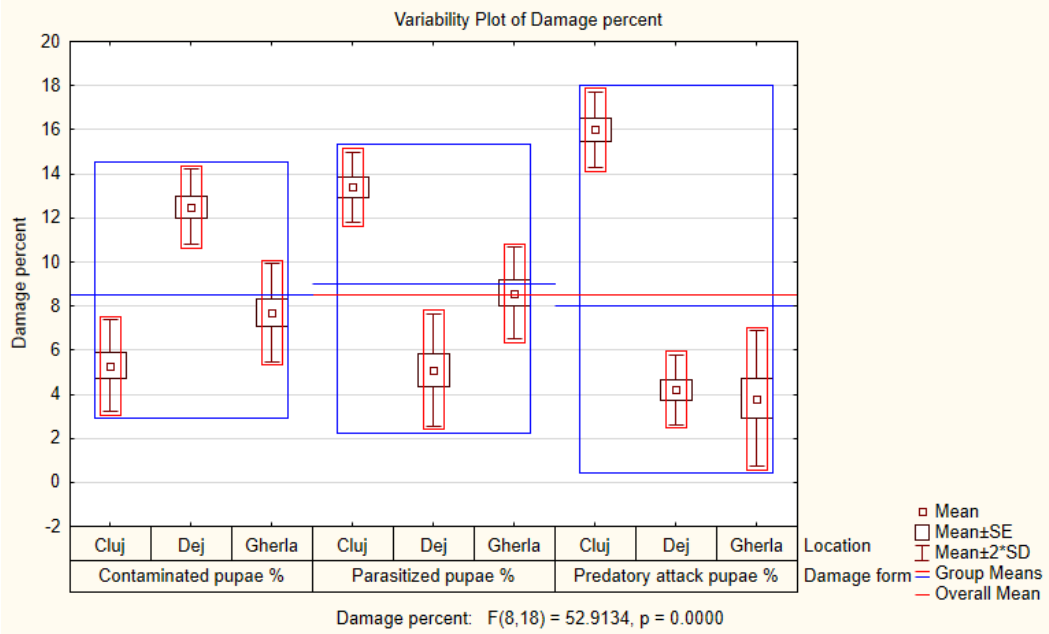

Figure 13. Percentage of Cydalima perspectalis Walker injury pupae by location and mode of damage (parasitism, predators, contamination) 
The highest percentage of infested pupae was reported in Dej, averaging $12.5 \%$. In the analyzed samples, this parameter ranged between $10.2 \%$ and $15.7 \%$. At Gherla, $7.7 \%$ of the pupae were contaminated by entomopathogenic microorganisms (between $4.6 \%$ and $9.8 \%$ ).

Biotic ecological factors have a cumulative contribution in diminishing the biological reserve of a pest. Let us analyze the total number of $C y$ dalima perspectalis pupae attacked by the zoophagous entomofauna on the three monitored localities. It is found that in Cluj-Napoca the percentage of attacked pupae is $29.4 \%$ (13.4\% parasites and 16\% predators), in Dej $9.3 \%$ (5.1\% parasites and $4.2 \%$ predators) and Gherla $12.4 \%$ (8.6\% parasites and $3.8 \%$ predators). Adding to this percentage the frequency of pupae contaminated by entomopathogenic microorganisms, we reach a total damage percentage of $34 \%$ in Cluj-Napoca, $21.8 \%$ in Dej and $20.1 \%$ in Gherla. The Figures 12 and 13 reveals that there are significant differences between the three locations but also regarding the mode of damage (parasitism, predators, contamination) of the species Cydalima perspectalis.

\section{Conclusions}

In the investigated area, it was found that in 2019 the entomopathogenic microorganisms contaminated the larvae and pupae of Cydalima perspectalis in a proportion of about 10\%. In two cities in northwestern of Romania, Cluj-Napoca and Ciucea, the presence of the larval endoparasite Exorista larvarum L. was reported. The treatments with synthetic pyrethroids and neonicotinoids determined the decrease of the frequency of pupae affected by zoophagous species. A number of 1-5 adults of Forficula auricularia L. have been reported on box tree bushes consuming pupae of Cydalima perspectalis (Walker, 1859).

\section{Authors' Contributions}

Conceptualization, I.B.H., T.F. and I.O.; methodology, I:B.H., T.F. and I.O; data analysis, V.F. and I.O.; validation, V.F.; formal analysis, I.B.H., V.F. and I.O; investigation, I.B.H., and T.F.; resources, I.B.H., and I.O.; writing-original draft preparation, I.B.H., and I.O; writing-review and editing, V.F.; supervision, I.O.

All authors read and approved the final manuscript.

\section{Acknowledgements}

This research received no specific grant from any funding agency in the public, commercial, or not-forprofit sectors.

\section{Conflict of Interests}

The authors declare that there are no conflicts of interest related to this article.

\section{References}

Agius J (2018). Pest species Cydalima perspectalis (Walker, 1859) new to the Maltese Islands (Lepidoptera: Crambidae). SHILAP Revista de Lepidopterología 46(184):577-579. 
Akatov VV (2015). Compensation reactions to the reduction of density of dominants in forest stands of the Western Caucasus. Contemporary Problems of Ecology 8(4):431-439. https://doi.org/10.1134/S1995425515040010

Bakay L, Kollár J (2018). The spread rate of Cydalima perspectalis (Walker 1859) in Slovakia (2013-2015). Plants in Urban Areas and Landscape 2018:51-54. https://doi.org/10.15414/PUAL/2018.51-54

Belokobylskij SA, Gninenko YuI (2016). A solitary endoparasitoid (Hymenoptera: Braconidae: Microgastrinae) of the severe Buxus pest Cydalima perspectalis (Lepidoptera: Crambidae) in the North Caucasus of Russia. Zoosystematica Rossica 25(2):248-254.

Billen W (2007). Diaphania perspectalis (Lepidoptera: Pyralidae), a new moth in Europe. Mitteilungen der Entomologischen Gesellschaft Basel 57(2/4):135-137.

Bird S, Raper C, Dale-Skey N, Salisbury A (2020). First records of two natural enemies of box tree moth, Cydalima perspectalis (Lepidoptera: Crambidae), in Britain. British Journal of Entomology and Natural History 33:67-70.

Brua C (2013). The box tree moth, Cydalima perspectalis (Walker, 1859), exotic invasive species, details of its invasion dynamics in france and europe, damage to box trees (Buxusspp) and management strategies., AFPP $-3^{\mathrm{e}}$ conférence sur l'entretien des espaces verts, jardins, gazons, forêts, zones aquatiques et autres zones non agricoles Toulouse, 15-17 Octobre 2013, pp 365-377.

Bunescu H, Florian T (2016). The box tree moth, Cydalima perspectalis Walker (Lepidoptera: Crambidae: Spilomelinae) a new invasive species in Cluj area (Romania). ProEnvironment/ProMediu 9:62-66.

Bury J, Olbrycht T, Mazur K, Babula P, Czudec P (2017). First records of the invasive box tree moth Cydalima perspectalis (Walker, 1859) (Lepidoptera: Crambidae) in south-eastern Poland. Fragmenta Faunistica 60(2):101-106. https://doi.org/10.3161/00159301FF2017.60.2.101

Di Vitantonio C (2016). Natural and anthropogenic factors affecting the life cycle of exotic and native insect species. 2016. PhD Thesis. Universita di Bologna.

Farahani S, Salehi M, Farashiani ME, Gilasian E, Terujeni SNK, Ahangaran Y (2018). Compsilura concinnata(Meigen), parasitoid of box tree moth, Cydalima perspectalis (Walker) from Iran. Iranian Journal of Forest and Range Protection Research 16(1):102-105.

Feás Sánchez X, Charles RJ (2019). Notes on the nest architecture and colony composition in winter of the yellow-legged Asian hornet, Vespa velutina Lepeletier 1836 (Hym.: Vespidae), in its introduced habitat in Galicia (NW Spain). Insects 10(8):237. https://doi.org/10.3390/insects10080237

Fora CG, Poşta DS (2015). Cydalima perspectalis Walk. (Lepidoptera: Crambidae), a dangerous pest of Buxus sempervirens in Timis County, Romania. Journal of Horticulture, Forestry and Biotechnology 19(3):26-32.

Göttig S, Herz A (2014). The box tree pyralid Cydalima perspectalis: New results of the use of biological control agents and pheromone traps in the field. Journal of Plant Diseases and Protection 121:98-99.

Göttig S, Herz A (2016). Are egg parasitoids of the genus Trichogramma (Hymenoptera: Trichogrammatidae) promising biological control agents for regulating the invasive Box tree pyralid, Cydalima perspectalis (Lep.: Crambidae)?. Biocontrol Science and Technology 26(11):1471-1488. https://doi.org/10.1080/09583157.2016.1211990

Göttig S, Herz A (2018). Susceptibility of the box tree pyralid Cydalima perspectalis Walker (Lepidoptera: Crambidae) to potential biological control agents Neem (NeemAzal $\left.{ }^{\circ}-\mathrm{T} / \mathrm{S}\right)$ and entomopathogenic nematodes (Nemastar ${ }^{\circ}$ ) assessed in laboratory bioassays and field trials. Journal of Plant Diseases and Protection 125(4):365-375. https://doi.org/10.1007/s41348-018-0154-8

Harizanova V, Naydenov M, Stoeva A, Valcheva I, Draganova D, Borisov Y, Mohamedova M (2018). Survey Of the gut pathogenic microflora associated with caterpillars of the box tree moth Cydalima perspectalis Walker, 1859 (Lepidoptera: Crambidae). Acta Entomologica Serbica 23(2):15-25. https://doi.org/10.5281/zenodo.2547665

Hellers M, Christian S (2016). Eine neue invasive Art in Luxemburg: der Buchsbaumzünsler Cydalima perspectalis (Walker). Bulletin de la Société des Naturalistes Luxembourgeois 118:131-134.

Herz A (2013). 1000 species for biological control - how to protect, enhance and use the diversity of beneficial organisms. Julius-Kühn-Archiv 54(436):54-61. https://doi.org/10.5073/jka.2012.436.007

Hizal E (2012). Two invasive alien insect species, Leptoglossus occidentals (Heteroptera: Coreidae) and Cydalima perspectalis (Lepidoptera: Crambidae), and their distribution and host plants in Istanbul Province, Turkey. Florida Entomologist 95:344-349. https://doi.org/10.2307/23268555

Iamandei M (2010). Diaphania perspectalis (Walker, 1859) (Lepidoptera: Crambidae) a new pest of Buxus spp. in Romania. Lucrari Stiintifice-USAMV Bucuresti. Seria B, Horticultura 54:787-793.

Kenis M, Nacambo S, Leuthardt FLG, Domenico FD, Haye T (2013). The box tree moth, Cydalima perspectalis, in Europe: horticultural pest or environmental disaster?. Aliens: The Invasive Species Bulletin (33):38-41. 
Krüger EO (2008). Glyphodes perspectalis (Walker, 1859) - new for the European fauna (Lepidoptera: Crambidae), Entomologische Zeitschrift 118(2):81-83.

Leuthardt F, Glauser G, Baur B (2013). Composition of alkaloids in different box tree varieties and their uptake by the box tree moth Cydalima perspectalis. Chemoecology 23(4):203-212. https://doi.org/10.1007/s00049-013-0134-1

Leuthardt LGF, Billen W, Baur B (2010). Ausbreitung des Buchsbaumzünslers Diaphania perspectalis (Lepidoptera, Pyralidae) in der Region Baseleine für die Schweizneue Schädlingsart. Entomo Helvetica 3:51-57.

Leuthardt FLG, Baur B (2013). Oviposition preference and larval development of the invasive moth Cydalima perspectalis on five European box-tree varieties. Journal of Applied Entomology 137:437-444. https://doi.org/10.1111/jen.12013

López C, Eizaguirre M (2019). Diapause and biological cycle of Cydalima perspectalis (Walker) in the eastern Pyrenees. Journal of Applied Entomology 143(10):1096-1104. https://doi.org/10.1111/jen.12709

Martin JC, Buradino M, Brinquin AS, Correard M, Thevenet J, Vauthier D, Tabone E (2018). Control the box-tree pyralid: limiting use of sexual synthetic pheromones and first non-scientific approach of the predation by Parus spp. In: Scientific Symposium on Boxwood Pests, 16-17 October 2018, Tours, France pp 179-185.

Martini A, Di Vitantonio C, Dindo ML (2019). Acceptance and suitability of the box tree moth Cydalima perspectalis as host for the tachinid parasitoid Exorista larvarum. Bulletin of Insectology 72(1):150-160.

Maruyama T, Shinkaji N (1987). Studies on the life cycle of the box-tree pyralid, Glyphodes perspectalis (Walker) (Lepidoptera: Pyralidae) I. Seasonal adult emergence and developmental velocity. Japanese Journal of Applied Entomology and Zoology 31:226-232. https://doi.org/10.1303/jjaez.31.226

Matsiakh I, Kramarets V, Mamadashvili G (2018). Box tree moth Cydalima perspectalis as a threat to the native populations of Buxus colchica in Republic of Georgia. Journal of the Entomological Research Society 20(2):2942.

Mostini L (2018). Bird predation on larvae of the box tree moth, Cydalima perspectalis (Walker, 1859). Rivista Italiana di Ornitologia 88(2):45-46. https://doi.org/10.4081/rio.2018.372

Nacambo S, Leuthardt FLG, Wan H, Li H, Haye T, Baur B, ... Kenis M (2014). Development characteristics of the boxtree moth Cydalima perspectalis and its potential distribution in Europe. Journal of Applied Entomology 138(12):14-26. https://doi.org/10.1111/jen.12078

Nagy A, Szarukán I, Csabai J, Molnár A, Molnár BP, Kárpáti Z, ... Tóth M (2017). Distribution of the box tree moth (Cydalima perspectalis Walker) in the north-eastern part of the Carpathian Basin with a new Ukrainian record and Hungarian data. EPPO Bulletin 47(2):279-282. https://doi.org/10.1111/epp.12384

Oltean I, Hulujan IB, Hulujan I, Varga M, Tötös Ş, Florian T (2017). Cydalima perspectalis Walker (Lepidoptera, Crambidae) a new dangerous pest report on Buxus sempervirens in Cluj area. Bulletin USAMV Cluj-Napoca. Agriculture 74(1):26-36. http://dx.doi.org/10.15835/buasvmcn-agr:12655

Perez CE, Guillem RM (2019). First records of the pest species Cydalima perspectalis (Walker, 1859) and Paysandisia archon (Burmeister, 1880) in Gibraltar (Lepidoptera: Crambidae \& Castniidae). Revista de la Sociedad Gaditana de Historia Natural 13:15-18.

Raineri V, Bonechi F, Caracciolo D, Cresta P, Mariotti M (2017). Cydalima perspectalis (Walker, 1859) (Lepidoptera, Crambidae) and the threats for the Nature 2000 habitat 5110 in Liguria (Nw-Italy). BMIB-Bollettino dei Musei e degli Istituti Biologici 79:215-236.

Rose J, Kleespies RG, Wang Y, Wennmann JT, Jehle JA (2013). On the susceptibility of the box tree moth Cydalima perspectalis to Anagrapha falcifera nucleopolyhedrovirus (AnfaNPV). Journal of Invertebrate Pathology 113(3):191-197. https://doi.org/10.1016/j.jip.2013.03.009

Shi HZ, Hu KF (2007). Occurrence regularity and control techniques of Diaphania perspectalis (Walker). Hubei Agricultural Sciences 46:76-78.

Székely L, Dinc V, Mihai C (2011). Cydalima perspectalis (Walker, 1859), a new species for the Romanian fauna (Lepidoptera: Crambidae: Spilomelinae). Buletin de Informare Entomologica 22(3-4):73-77.

Tabone E, Enriquez T, Venard M, Colombel E, Gutleben C, Guérin M, ... Martin JC (2015). Development of a biocontrol program against the box tree moth Cydalima perspectalis (Walker, 1859). In: IUFRO WP Population dynamics and integrated control of forest defoliating and other insects. Sep 2015, Sopot, Poland pp 83.

Van der Straten MJ, Tymo ST, Muus M (2010). The box tree pyralid, Glyphodes perspectalis (Lepidoptera: Crambidae), an invasive alien moth ruining box trees. Proceedings of the Netherlands Entomological Society Meeting 21:107111. 
Valigurová A, Michalková V, Koník P, Dindo ML, Gelnar M, Vaňhara J (2014). Penetration and encapsulation of the larval endoparasitoid Exorista larvarum (Diptera: Tachinidae) in the factitious host Galleria mellonella (Lepidoptera: Pyralidae). Bulletin of Entomological Research 104(2):203-212. https://doi.org/10.1017/S0007485313000655

Wan H, Haye T, Kenis M, Nacambo S, Xu H, Zhang F, Li H (2014). Biology and natural enemies of Cydalima perspectalis in Asia: Is there biological control potential in Europe?. Journal of Applied Entomology 138(10):715-722. https://doi.org/10.1111/jen.12132

Zamani SM, Farahani S, Farashiani ME, Salehi M, Samavat S (2017). The first record of Beauveria bassiana on box tree moth, Cydalima perspectalis in Iran. Iranian Journal of Forest and Range Protection Research 15(2):199-202.
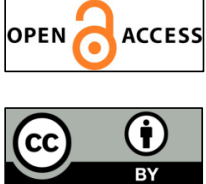

The journal offers free, immediate, and unrestricted access to peer-reviewed research and scholarly work. Users are allowed to read, download, copy, distribute, print, search, or link to the full texts of the articles, or use them for any other lawful purpose, without asking prior permission from the publisher or the author.

License - Articles published in Notulae Botanicae Horti Agrobotanici Cluj-Napoca are Open-Access, distributed under the terms and conditions of the Creative Commons Attribution (CC BY 4.0) License. (c) Articles by the authors; UASVM, Cluj-Napoca, Romania. The journal allows the author(s) to hold the copyright/to retain publishing rights without restriction. 